\title{
Chapter 4: Coaching as an Entrepreneurship Learning and Development Tool
}

\section{By Duminda Rajasinghe and Dr. Hala Mansour}

\section{Introduction}

The growing body of literature discusses coaching as a learning and developmental tool (see for example, (Bennett and Campone, 2017; Gray et al., 2016; Du Toit, 2014). There is evidence that coaching differentiates itself from traditional learning and developmental interventions which are structured, reductionist and dominant (Garvey, 2011). This dominance in traditional learning is partly due to the positivistic or modernist view of education that has been influenced by psychology (Garvey, 2017; Bachkirova and Kaufman, 2008). In addition, despite demands to seek effective ways of developing adults in their entrepreneurial abilities, the responsible institutes and individuals (e.g. Business Schools) have been accommodating techniques that are more conversant with the positivistic instance and early adult learning theories. One possible reason for this is to cater to the societal demands to develop measurable programmes with a distinct start and an end which follow the linear model of learning (Garvey, 2011). The trend of creating measurable programmes has also been growing in business organisations (public, privet, social, non-for-profit etc.) which are generally believers of 'objectivity' in most of their business activities (See Garvey et al., 2017).

It has been argued that this logic helps institutes to set measurable objectives and learning outcomes that are easy to follow and evaluate. Therefore, with following these traditional leaning interventions, it may be easier 'to judge success in teaching and learning' than using, for example, coaching as an entrepreneurship development tool (Garvey et al., 2017:110). However, it is important to continue questioning the reasons of why some practitioners and decision-makers believe that the traditional learning interventions are the best way for learning. 
The debate around this point develop a deeper understanding of entrepreneurship and entrepreneurship learning and is a current need within the industry (Blundel, et al.2017).

In this chapter, we suggest coaching as an appropriate entrepreneurship learning and development tool and it is an alternative to the dominant reductionist way of learning and development. However, we acknowledge that there are different ways of entrepreneurship learning and development which may appear equally relevant and valid. We do not discard any of them and their abilities and relevance but aim to develop a conceptual rationale on how coaching may link to entrepreneurship learning.

\section{Entrepreneurship}

We believe that entrepreneurship is subjected to multiple interpretations (Blundel, et al., 2017). The contributors to this textbook have already discussed this in detail so we do not aim to repeat those discussions here. The aim here is to set the context for this chapter discussing our position on entrepreneurship. This in return helps to justify coaching as a potential tool for entrepreneurship learning and development.

There appears no consensus about what entrepreneurship is or what skills and abilities an individual should have to become an entrepreneur (Blundel, et al., 2017). The concept in general interpreted as an innovator who takes risks of investing assets (both physical and intellectual) to address a social need ensuring the sustainability both for the organisation and for wider stakeholders. It does not appear to be necessary that an entrepreneur always a person who creates a new venture.

However, what is clear is that to become an entrepreneur, an individual should be innovative and creative, the attitude and commitment to contribute, motivation to continue whilst addressing issues effectively. It is also recognised that openness and risk taking, and continuous 
learning are some necessary elements of entrepreneurial abilities/skills. The list is not conclusive. However, it is understandable as entrepreneurship is situated in context (Brannback and Carsrud, 2016), and socially constructed (Anderson, 2016; Pittaway, 2000). So, we see it as a complex non-linear social process. Therefore, skills, abilities and even the way entrepreneurship is viewed can be changed depending on the context (Blundel, et al., 2017). If entrepreneurship is viewed, interpreted and practice different in different context, the entrepreneurship learning, and teaching should take these contextual and subjective elements into consideration. We, therefore, see a possibility of more effective outcomes if we are to tailor entrepreneurship learning and development. Coaching appears as a potential tool for the purpose.

It is also important to note that scholars and practitioners continue to argue whether entrepreneurship can be learned and developed. This is similar to the argument in leadership development which to date has no consensus (Northouse, 2016). These different constructs are part of the lived world as actors continue to engage in activities they also create meaning for them. The chapter, therefore, accepts the possibilities of different constructs within a contextual and subjective phenomenon like entrepreneurship. The beauty that implants the phenomenon due to its subjective nature inspires to explore coaching as a potential intervention to learn and develop entrepreneurship. Therefore, this chapter is more interested in developmental discourse rather than the born or heredity concepts within it. Thus, it takes the developmental view forward and attempts to justify how coaching fits for the purpose.

\section{Adult Learning Theories and Entrepreneurship Learning and Development}

The above discussion sets the foundation for this chapter. Entrepreneurs as adults can be considered as more responsible, dedicated and self-driven. They choose to learn and develop themselves as future entrepreneurs. This view encourages us to explore how adults learn and 
relevance of them to entrepreneurship learning and development. However, this chapter does not aim to develop a comprehensive discussion on existing adult learning theories but the ones that appear more relevant to the context of this chapter.

\subsection{Theories of Adult Learning and Entrepreneurship Learning and Development}

The earliest theories of adult learning were based on behaviourist approaches (Skinner, 1976; Pavlov, 1927). These were highly fitting to the context of the time as they appeared scientific and functional. The belief within this school was that learning creates behavioural changes (Jarvis et al., 1998). Focusing on objectively observable behaviours, these theorists discounted independence that individuals have in their activities of the mind. This mode of learning for the current business entrepreneurial learning and development is questionable. There appears a high demand for creativity, innovation and adaptability from the emerging entrepreneurial leaders in the context of business in $21^{\text {st }}$ century. A controlled and structured way of learning does not appear to facilitate those skills and attributes that are in demand (see Garvey et al., 2017).

The behaviourist theorists were followed by cognitive theorists where learning was considered as a mental process. For example, Piaget (1929) developed his stages theory and Vygotsky (1978) established the idea of a proximal development zone and contributed to the evolutionary thinking of adult learning. This is where the idea of 'scaffolding' (see Wood et al., 1976) to indicate the importance of someone's (a learned) support to facilitate learning. The idea of 'scaffolding' may also mean the temporary nature of the support recognising the responsibility and commitment that learners should be developing to be independent. On the other hand, it is also an acceptance of the value of social learning and collaboration (Gray et al., 2016). These apparently linked with the concepts of coaching and entrepreneurship learning and development (see Pittaway and Thorpe, 2012). 
These theories are criticised for having their focus on child learning and development and most early theories appear to suggest a liner, controlled and closed approach to learning (Garvey, 2011). Recognising that the adults learn differently compared to children, Knowles (1975) introduced the idea of 'andragogy'. Theory invites educators and the researchers to look at adults as responsible, committed and self-motivated individuals who learn and develop themselves for a reason (Knowles et al., 2015).

Knowles (1984) describes early pedagogical models of learning as traditional modes of learning. He notes that this was the only way of learning that the whole world knew since the beginning of school systems in the seventh century. The model was teacher centred and the learner was a dependant. The authority lies within the so-called expert teacher and the readiness to learn was considered a function of age (Knowles, 1984). This dominant model of learning according to Garvey (1994) appears to enforce pressure for improved performance, linear and controlled development. This idea is in line with Garvey's (2011) "mass societal construction of learning" (p.57) which positions learning in stages or phases. In his view, this linear view of learning is appealing to educators and to educational institutes. These stages and phases of learning do not seem to have, at least, considered the individual differences, contextual and subjective implications of learning in theorising these concepts. However, if we are to take our view of entrepreneurship and entrepreneurship learning, it is important that we consider these implications and question the existing practices. Yet, it has become difficult to challenge these views as "we have become so used to this approach that we no longer notice it" (Garvey, 2017:685). The difficulties of going against such dominance also appear to hinder researchers and practitioners from exploring innovative ways of learning (Gray et al., 2016). This dominance is partly due to early influences and reliance of education in psychology and educational psychology (Merriam, 2001). According to Merriam (2001) educators until mid$20^{\text {th }}$ century relied on psychology and educational psychology research to understand adult 
learning. Therefore, the positivist tendency of early adult learning theories is understandable (Bachkirova, 2017).

However, Knowles' (1984) contribution of andragogy develops constructive thinking and approaches to adult learning. Knowles (1984) highlighted the notion of self-directed learning. He emphasises this by saying "an adult is one who has arrived at a self-concept of being responsible for one's own life, of being self-directing" (p.9). So, people have a desire to learn from each other as they act as rich resources to one another to develop their knowledge, skills and to enhance performance (Garvey et al., 2014; Knowles, 1984). The andragogy model also assumes that the readiness to learn occurs with a "need to know or do something in order to perform more effectively" (Knowles, 1984:11). Further, adults having that need; enter into learning with life, task, problem, and experience-centred learning. These also appear as primary ways of entrepreneurship learning and development. For example, learning on the job or experiential learning has been considered as a primal in entrepreneurship learning (Jones, Macpherson and Woolland, 2008; Rae, 2002; Rae and Carswell, 2000). The contextual nature of entrepreneurial learning also requires entrepreneurs to change their behaviours, approaches, business strategies (Deakins and Freel, 1998). Therefore, entrepreneurial learning should be a continuous social process rather than an activity that has a definite start and an end.

Literature also discusses that reflection is also relevant to entrepreneurial learning. The widely accepted experiential learning may not be of any use if entrepreneurs do not engage in a critical and analytical debate to enhance their practice and learn from their experience. In doing so, critical reflection on their experience, despite it being a positive or a negative experience appears to help entrepreneurs to learn and develop (Cope, 2003; Gibb, 1997). Cope (2010) also identifies learning from failure as a key aspect of learning. Therefore, experience does not have to be positive at all times. Literature supports this view further by highlighting the importance of having some space to make mistakes (see Johnston, Hamilton and Zhang, 2008). 
In addition, 'Know thyself' the eternal caption appears throughout the past and in the temple of Apollo at Delphi dating 2000 years ago (Cairns-Lee, 2015) continues to appear as relevant to entrepreneurial learning (Tseng, 2013). This does not mean the relevance of learning about the organisation, the industry; developing relationships and actively engaging in these relationships to create mutual improvements are neglected in entrepreneurship learning and development. This shows the dynamic nature of the phenomenon.

Entrepreneurial engagement appears as a temporal and context-specific activity (Cope, 2010). Pittaway et al. (2015) also agree the contextual and the situational nature of the entrepreneurship learning. This relates to social and situated learning (Lave and Wenger, 1991) and appears relevant in the context of entrepreneurship learning. Therefore, agreeing on a way of learning for entrepreneurship learning is beyond the realities that may exist. However, Cope (2005) suggests some relevant and appropriate common grounds of entrepreneurial development. According to Cope (2005), transformative learning (Mezirow, 1991), situated learning (Reynolds and Mason, 2002; Lave and Wenger, 1991; Bandura, 1977), adaptive learning (Deakins and Freel, 1998; Watts, Cope and Hulme, 1998) and reflective learning (Brockbank and McGill, 2012; Argyris \& Schön; 1996; Argyris, 1960). These appear to link well with the concepts of coaching.

Adults (entrepreneurs) learn not for the sake of learning (Knowles, et al., 2015) but for a purpose. The discussion within this chapter continues to place its focus on this and believe that the entrepreneurs or the potential entrepreneurs aim to learn for a purpose. However, we acknowledge that the meaning of 'adult' and the parameters that define 'adulthood' may also vary according to the context (for example 'legally or socially accepted adulthood, biological adulthood). It is also questionable if someone has to be an adult to become an entrepreneur. We leave some of these questions to the readers to explore. 
Despite the above possibilities of different interpretations, there is sufficient evidence to argue that there is no one universal way of learning entrepreneurship (Blundel et al., 2017). This also links well with our position of entrepreneurship for this chapter.

The traditional model of learning can be labelled as a 'content model' whereas andragogy focuses on the process (Garvey, 2011). Knowles et al. (2015) distinguish the process from the content saying that "the process model is concerned with providing procedures and resources for helping learners to acquire information and skills" (p.51). Knowles et al. (2015) argue that despite all these development, there is a great deal of unknown of how humans learn and develop. The diversity presence within individual learners, contexts that learners are in and their interpretation of learning appears to create difficulties of understanding how entrepreneurs learn. To accommodate these difficulties, it can be argued that coaching can be a fruitful approach to learning and development. The acceptance of the above diversity also helps to understand the divisions of theories from content to process, modern to traditional and child development to adult. It was however clear that andragogy, experiential learning and transformative learning theories "are the heart of all adult learning and development and consequently are the heart of coaching practice" (Bachkirova, et al., 2014:8). Bachkirova and colleagues further argue that andragogy (Knowles, 1984), experiential learning (Kolb, 1984) and transformative learning (Mezirow, 1991) represent the very nature of coaching. This links with Cope's (2005) identification of common grounds of entrepreneurial learning.

To develop further understanding of how the coaching support entrepreneurship learning and development. The theories of coaching discussed below. First, the below section discusses the origin of coaching to highlight the developmental links that it has since its inception. 


\section{Coaching}

Coaching defined as 'a support structure based on a close interpersonal relationship leading to learning and the development of potential, often within a context of change' (Audet \& Couteret, 2012: 516). Therefore, coaching does not seek to provide managers with specific skills to address specific needs, but it helps entrepreneurs to 'grow as people' so they can widen their personal horizon (Thompson and Downing, 2007). Therefore, there is a leaning attached to coaching. Commitment to the relationship is one of the main success factors that affecting coaching (Auddet and Couteret, 2012). This is also an important factor to be considered for entrepreneurship education and the level of commitment influence directly the outputs of the learning

The origin of coaching is in surrounded speculations (Gray et al., 2016). Zeus and Skiffington (2000) argue that few writers link coaching to the primordial era citing that it has been used to improve hunting skills. De Haan (2008) noted that some relate coaching to Socratic teachings and another discourse is that coaching originates from the practice of coaching people in sports to improve their performance (Whitmore, 2012; Wilson, 2007; Starr, 2003; Witherspoon and White, 1996).

However, Garvey (2011) highlights a broader perspective of the initial uses of coaching. He emphasises that coaching has been used in tutoring for academic performance, performance improvements in boating and rowing, teaching the defence of the wicket in cricket and developing subject matter expertise. Therefore, there are diverse arguments about the inception of coaching, where it started, when and in what field.

This diversity is also apparent within the word 'coach'. For example, Gray (2006) argues that the term coach was first used in the $16^{\text {th }}$ century to describe a carriage that conveys people to the desired destination. In a similar vein, some (Underhill et al., 2007; Stern, 2004; 
Witherspoon and White, 1996), believe that the word originates from a Hungarian village called Kocs where passenger wagons were first developed to carry people to their desired destinations. This notion is challenged by Athanasopoulou and Dopson (2015) highlighting the possibility that this idea is a myth. However, they agree that myths are part of a phenomenon worth mentioning. Integrating the coach (wagon, the noun) and also the coach (the verb), some (Gray et al., 2016; Garvey, 2011) claim that the word's origin (in the English language) is in William Thackeray's novel, Pendennis published in 1849. This meant "both moving from A to B in a coach and to coach for academic attainment at Oxford University" (Garvey, 2011:12). However, Maltbia et al. (2014) believe that the origin of the word coaching in the English language goes back to 1500 s. Therefore, it is clear that there are different arguments about the origin of the word, where it was first used and why.

Despite these contradictory arguments of the origin of the coaching (noun) and the coaching practice, there is an apparent 'performative' and 'developmental' link attributed to it since its inception (Garvey et al., 2014; Garvey, 2011).

This developmental link is also evident through the earliest publication on coaching (Gorby, 1937) that coaching scholars (Passmore and Fillery-Travis, 2011; Grant et al., 2009) traced back to. Gorby's study explored the implications of coaching in a manufacturing industry. This research was criticised for its limitations of methods but it "signals the potential of coaching as a force for good in organisations" (Passmore Fillery-Travis, 2011:70).

However, the growth of coaching as a commercial activity (Garvey, et al., 2014; Garvey, 2011; Wilson, 2007) has generated diverse modes of coaching (life coaching, business coaching, executive/leadership coaching, developmental coaching, team coaching, transformational coaching and the list is not conclusive) into this relatively new profession (Wilson, 2007). Confusions surrounded by the profession may be due to its diverse uses, evident popularity 
(Western, 2012; Passmore, 2007) and commercialisation of the activity (Garvey et al., 2014). However, "a central discourse of more modern developments in coaching continues to be performance improvement" (Gray et al., 2016:15) and development. One of the popular uses of coaching is for leadership development (Korotov, 2017; De Haan et al., 2013; Ely et al., 2010) this is also considered as one of the main reason for increasing popularity of coaching (De Villiers, 2012; Segers et al., 2011). These suggest the possibilities lie within coaching to operate as an entrepreneurship learning and development. There are some attempts to incorporate coaching for entrepreneurship learning and development; however, the potential within the tool for the purpose appears high. Therefore, there is space for scholars, practitioners and policymakers to explore the possibilities of coaching further. The unique nature of coaching as a development intervention compared to conventional interventions seems to make coaching more attractive for learning and development. The below section discusses the uniqueness of coaching.

\subsection{Coaching is a unique Developmental Intervention}

Coaching appears to offer a different approach to learning and development with a strong focus on individual development needs (Passmore and Fillery-Travis, 2011; Kilburg, 1996). It most often happens in their natural environment. Coaching is more person-centred (Grant, 2014; Theeboom et al., 2014; De Haan at al., 2013) and holistic than traditional training and development (Abbott et al, 2006; King and Eaton, 1999). Additionally, coachee (entrepreneur in this context) within the coaching engagement has a much greater say about his/her development which in turn makes coaching more relevant for their development (Giglio et al., 1998; Tobias, 1996). The idea of having authority and responsibility within the learning links well with andragogy and transformational learning. This also appears to suit entrepreneurs as there is space for them to keep their confidence and authority within the process.

Citation for this Chapter: Rajasinghe, D., \& Mansour, H. F. (2019). Coaching as an entrepreneurship learning and development tool. In 11 G. Mulholland \& J. Turner (Eds.), Enterprising education in UK higher education: Challenges for theory and practice (pp. 52-69). London: Routledge. 
Moreover, contextually embedded nature of entrepreneurship learning and development influences the development intervention to consider culture, operating environment, technology and their wider implications for entrepreneurship learning. This hints the possibilities of different styles of learning by different individuals. The learning styles and the critiques of them is a separate topic (see Coffield et al., 2004; Honey and Mumford, 1982; Kolb and Fry, 1975) which we do not intend to go into detail here. However, coaching appears to accommodate different styles of learning (Bowerman and Collins, 1999). Another unique feature of executive coaching is tailoring development for individual coachees through empowering them and providing authority to draft their own development plans, so it encourages learner-centred development (De Haan et al., 2013; Garvey, 2011). This also appears to address some of the issues related to the responsibility for learning and development and to the issues of 'mass societal learning'.

Moreover, coaching is said to explore ways of helping, facilitating their learning and development by engaging in a genuine developmental relationship that is non-judgemental and supportive (Ladegard and Gjerde, 2014; Wang, 2012; Hudson, 1999; Giglio et al., 1998; Kilburg, 1996). This developmental relationship also appears as a unique feature that distinguishes it from conventional training and development (Hamlin et al., 2016; Hudson, 1999; Giglio et al., 1998; Kilburg, 1996) because it encourages individuals to be confident and act on their development (Wang, 2012; Baron et al., 2011; Hudson, 1999). Narayanasamy and Penney (2014) supported by MacKie (2016), Grant (2014), De Haan et al. (2013), Batson and Yoder (2012), King and Eaton (1999), Gigilo et al. (1998) acknowledge the role of coaching in motivating individuals to reach their potentials. Coaching appears to tap into intrinsic motivation to encourage learning and development. We believe that these aspects of coaching has more potential to encourage entrepreneurs to continue to learn. 
The non-judgemental relationship developed with the coach is also considered as space for coachees to explore possibilities develop their own critiques of the plans /actions etc. that they are to work on. Critical questions and challenges from the coach apparently help coachees to critically reflect on what they do and also their predispositions (Brockbank and McGill, 2012; Mezirow, 1991). The gradually developed trust enhances the relationship between the coach and the coachee is said to be more open to discuss things and for the challenges that comes on his way. The relationship itself, the mutual understanding, the support from the coach, and the trust seems to motivate the coachee to continue to work on the developmental gaps that agreed to work on. Is not that something entrepreneurs can benefit? For an entrepreneur to find himself, understand his/her strengths weakness etc it is important that he engage with an open discussion with someonewho is trained to facilitate such conversation (Brockbank and McGill, 2012). The trust developed and the non-judgemental nature of the relationship seems to facilitate conversational learning.

Coaching also has a build in evaluation which appears to contribute to the social capital development of the individual coachees (Saunders, 2006). Thus "the evaluator works more as a partner, generating supplementary perspectives, enabling conversations, introducing new ideas about the evaluation logic and facilitating the examination and critique (Schwandt, 1997:79). This links with the idea of reflective practices for development (see Ling, 2012). The challenging questions-based conversation apparently helps learners (coachees) to change their predispositions (Mezirow, 1991) which results in positive behavioural changes. Therefore, it becomes a participatory and inclusive method of evaluation (Garvey, 2017; Saunders, 2006) which is developmental. This, then, is more appropriate for entrepreneurship learning and development assessments. It becomes more relevant if we are to assume that the main purpose of the learners who enrol for entrepreneurship development programmes is to learn and develop their skills and experience. 
A summary of how coaching may link with the concepts of andragogy is in the below table.

\begin{tabular}{|c|c|c|}
\hline Element & Andragogy Approach & Coaching \\
\hline $\begin{array}{l}\text { Preparing } \\
\text { Learners }\end{array}$ & $\begin{array}{l}\text { Provide information, prepare for } \\
\text { participation, help develop realistic } \\
\text { expectations, begging thinking about } \\
\text { the content }\end{array}$ & $\begin{array}{l}\text { Through a conversation, it prepares } \\
\text { learners to set their own expectations, } \\
\text { what they would like to achieve, how } \\
\text { they are planning to achieve them. }\end{array}$ \\
\hline Climate & $\begin{array}{l}\text { Relaxed, trusting, Mutual respect } \\
\text { Informal, warm, Collaborative, } \\
\text { supportive, Openness and } \\
\text { authenticity, Humanness }\end{array}$ & $\begin{array}{l}\text { Non-directive, non-judgmental nature } \\
\text { of coaching appears to support all } \\
\text { these elements in andragogy approach }\end{array}$ \\
\hline Planning & $\begin{array}{l}\text { Mechanism for mutual planning by } \\
\text { learners and facilitator }\end{array}$ & $\begin{array}{l}\text { Mutual agreement of the expectations } \\
\text { and how to go about achieving what } \\
\text { is agreed }\end{array}$ \\
\hline $\begin{array}{l}\text { Diagnosis of } \\
\text { needs }\end{array}$ & By mutual assessment & $\begin{array}{l}\text { Through conversation , mutual } \\
\text { agreement and analysis }\end{array}$ \\
\hline $\begin{array}{l}\text { Setting of } \\
\text { objectives }\end{array}$ & By mutual negotiation & $\begin{array}{l}\text { Mutual analysis and understanding } \\
\text { but coachee-led }\end{array}$ \\
\hline $\begin{array}{l}\text { Designing } \\
\text { learning plans }\end{array}$ & $\begin{array}{l}\text { Sequence by readiness } \\
\text { Problem units }\end{array}$ & $\begin{array}{l}\text { coachee readiness, willingness, } \\
\text { ability, contextual support and } \\
\text { importance would be considered }\end{array}$ \\
\hline $\begin{array}{l}\text { Learning } \\
\text { activities }\end{array}$ & Experiential techniques (inquiry) & $\begin{array}{l}\text { Socially and contextually embedded. } \\
\text { The learners stay and continue to be } \\
\text { in his/her operating environment. } \\
\text { Thus complies with the experiential } \\
\text { techniques of andragogy. }\end{array}$ \\
\hline Evaluation & $\begin{array}{l}\text { Mutual re-diagnosis of needs } \\
\text { Mutual measurement of program }\end{array}$ & $\begin{array}{l}\text { Evaluation is on-going, } \\
\text { conversational, formative and } \\
\text { developmental. Both coachee and the } \\
\text { coach are part of the assessment }\end{array}$ \\
\hline
\end{tabular}

Table 4.1: Andragogy and Coaching ( adapted from Knowles et 2015) 
The table (4.1) supports Konwles'(1975) notion that people learn best when the learning environment is trusting, and informal. The concept of andragogy also believes the ability of learners and acknowledges the importance of creating space for individuals to plan and work on their development. The traditional and closed approaches to learning do not appear to take these into account (Garvey, 2011) and aim to create development through 'one-size-fit for all' type of modes of learning and teaching. This also contradicts with diversity presents within entrepreneurship and entrepreneurship learning (see Blundel et al., 2017). Such programmes also appear to ignore diversity within learners, different abilities and purpose of learning.

Mezirow (1991) emphasises the importance of a perceptual change and sense of possibilities to facilitate learning. Therefore, it is important to challenge one's own meaning schemas to create deeper learning is highlighted. However, the difficulties in changing deep-rooted meaning perspectives are acknowledged (Du Toit, 2014; Bachkirova et al., 2014; Askew and Carnell, 2012). In transformative learning, critical reflection "necessitates the suspension of judgment about the truth or falsity of ideas, until a better determination can be made" (Mezirow, 2000:13). Through analysing "self' during the transformative process, it is believed that there is a reorientation that 'results [in] deep learning and revised action" (Bachkirova, et al., 2014:8). The possibility of facilitating these through traditional modes of learning with content or stage focus seems difficult. Therefore, andragogy informed open curriculum appears relevant entrepreneurship learning and development. Coaching as discussed above seems to facilitate such approach in an informal learning environment (Hunt and Fielden, 2016; Audet and Couteret, 2012).

\subsection{Issue that may encounter}

Coaching is an expensive intervention. Therefore, funding to implement coaching schemes in higher education would be challenging. This applies to early entrepreneurs who seek support from professional coaches. Tailored nature of it also brings challenges in practical application, 
especially in higher education. First, the majority of the educators have been part of mass societal learning (Garvey, 2011) and are reluctant to change their way of teaching delivery. The administration of individualised activities like coaching adds more costs in terms of resource requirements.

Subjective nature of coaching and apparent andragogy led open curriculum within it may be a challenge for an established mode of learning and development in institutions. Therefore, working against the dominant view of learning and development will bring institutional policies and procedures into the context. So, introducing coaching for the purpose may also require policy changes and attitudinal changes of the established institutes towards learning and development

In addition, Return on Investment (ROI) in monetary terms will be a demand as the initiative is costly. However, it is arguable that attempting to narrow people development into financial return on investment as mechanistic (see Grant, 2012). Despite the available theoretical support for the argument, the idea will be contested in the practice. Entrepreneurs' readiness to engage with an outsider (a coach) should also be taken into consideration. For example, ego issues, financial affordability etc. likely to play a role in employing coaching.

On the positive side, there are concepts like peer coaching, and team coaching that is possibly more practical in the UK higher education compared to one-to-one coaching at least to start with. Peer coaching and Team coaching may also be helpful for entrepreneurs to develop their professional network which in the current context of the business appears mandatory for success.

The future of coaching and entrepreneurship education will focus on creating an organisational culture to support creativity, active understanding and emotional involvement. This will have many connections with learning as an active process and how to develop the identity of 
learners. Therefore, coaching could help to support entrepreneurial learning 'to recognise and act on opportunities and be interacting socially to initiate, organise and manage venture's (Rae, 2002)

\subsection{Research in Coaching for Entrepreneurship Development}

Coaching and entrepreneurship coaching research have been growing since its first publication in 1937. However, it still appears as a relatively new concept (Grief, 2017). Yet, there appears sufficient evidence within coaching that any interested parties now can rely on. The debates and dilemmas around the subject continue to appear so there is a demand for further empirical evidence to resolve such issues. Coaching, therefore, is in need of more research and there are positive signs of growth (Bachkirova, 2017).

There are also positive signs of research growth within entrepreneurship research (Blundel et al., 2017) and promising research trends in entrepreneurship education and development which are moving towards wider-range of study subjects and programmes by creating multidisciplinary links (Wilson, 2008). However, coaching as an entrepreneurship development intervention appears to be under-researched and discussed. The relevance of coaching as an entrepreneurship learning and development tool needs further justification and research informed rationale (Audet and Couteret, 2012). The issues that are raised above in terms of practical application of coaching seems to have implication for entrepreneurship educators to not to consider coaching as a potential intervention. On the positive note, there is some attention on coaching as an entrepreneurship learning and development (see Hunt and Fielden, 2016; Gracia, 2015; Audet and Couteret, 2012) tool that needs further strengthen in near future. The scholarly evidence appears importance for the growth of the industry and to make it more innovative and creative. This chapter will also be a valuable addition to the rising discussions within the field. There is also possibility that the existing support for coaching as a leadership development intervention (Korotov, 2017; De Haan et al., 2013; Ely et al., 2010) 
is used to make sense of the prospect of coaching as an 'entrepreneurship learning and development tool' at least until a sufficient research-based is developed. This may lay a sound foundation for open innovation in entrepreneurship learning and teaching.

\section{Conclusion}

This chapter explored coaching as an entrepreneurship developmental tool. The discussions demonstrate some evidence and critical analysis for scholars and practitioners to develop the idea further. It is also realised that there is a scarcity of research within the field of entrepreneurship coaching and this chapter appears as one of the early conceptual suggestion to further investigate the potential through empirical studies.

The chapter may appear biased towards the social constructionist view of research. However, there is no attempt to discard other potential worldviews here. In addition, the acceptance of social construction may consider as an indirect acceptance of other realities that may exist. Therefore, this chapter encourages researchers to construct knowledge and enhanced understanding using diverse methodologies and methods. It also encourages practitioners in the field to explore possibilities of coaching as a learning and development tool for entrepreneurship.

The established arguments may also help students, researchers, entrepreneurs, business schools and wider entrepreneurial community to develop their understanding. It also encourages then to look at entrepreneurship and entrepreneurship education differently understanding the subjective and contextual nature of the phenomenon.

The chapter provides a discussion about coaching as a tool to develop the skills of entrepreneurs rather than the traditional tools that often focus on the tangible and assessable outcome of a business plan. This requires considering interdisciplinary connections among subjects and 
departments and adopting new teaching and learning philosophy and practices that mainly based on achieving social interacting and building an active learning environment.

\section{References}

Abbott, G. N., Stening, B. W., Atkins, P. W. B. and Grant, A. M. (2006), Coaching expatriate managers for success: adding value beyond training and mentoring, Asia Pacific Journal of Human Resources. 44(3), pp. 295-317

Anderson, A. R. (2016), The economic reification of entrepreneurship: re-engaging with the social, In: Fayolle, A. and Riot, P. (eds.), Rethinking Entrepreneurship: Debating research orientations, Oxon, Routledge, pp. 44-56

Audet, J. and Couteret, P., (2012), Coaching the entrepreneur: features and success factors, Journal of small business and enterprise development, 19 (3), pp.515-531

Argyris, C. (1960) Understanding organizational behaviour, Homewood: Dorsey.

Argyris, C. \& Schön, D. (1996) Organisational learning II: theory, method and practice,

Wokingham: Addison-Wesley

Askew, S. and Carnell, E. (2011), Transformative coaching: a learning theory for practice. London: Institute of Education, University of London

Athanasopoulou, A. and Dopson, S. (2015), Developing leaders by executive coaching: practice and evidence, Oxford: Oxford University Press

Audet, J. and Couteret, P. (2012), coaching the entrepreneur: features and success factors, Journal of Small Business and Enterprise Development, 19(3), pp.515-531

Bachkirova, T. (2017), developing a knowledge base of coaching: questions to explore. In: Bachkirova, T., Spence, G. and Drake, D. (eds), Sage handbook of coaching. London: Sage Publications Ltd, pp. 23-41

Bachkirova, T., Cox, E. and Clutterbuck, D. (2014), Introduction, In: Cox, E., Bachkirova, T. and Clutterbuck, D. (eds), The complete handbook of coaching, $2^{\text {nd }}$ ed. London: Sage Publications Ltd, pp. 1-18

Citation for this Chapter: Rajasinghe, D., \& Mansour, H. F. (2019). Coaching as an entrepreneurship learning and development tool. In 19 G. Mulholland \& J. Turner (Eds.), Enterprising education in UK higher education: Challenges for theory and practice (pp. 52-69). London: Routledge. 
Bachkirova, T. and Kauffman, C (2008), many ways of knowing: How to make sense of different research perspectives in studies of coaching, Coaching: an international journal of theory, research and practice, 1(2), pp.107-113.

Bandura, A (1977), Self-efficacy: toward a unifying theory of behavioural change, Psychological Review, 84(2), pp.191-215

Baron, L., Morin, L. and Morin, D. (2011), Executive coaching: the effect of working alliance discrepancy on the development of coachees' self-efficacy. Journal of Management Development, 30(9), pp.847-864

Batson, V. D. and Yoder, L.H. (2012), Managerial coaching: a concept analysis." Journal of Advanced Nursing, 68(7), pp. 1658-1669

Bennett, J. L. and Campone, F. (2017). Coaching and theories of learning. In: Bachkirova, T., Spence, G. and Drake, D. (eds), Sage handbook of coaching. London: Sage Publications Ltd, pp. $102-120$

Bowerman, J. and Collins, G. (1999), The coaching network: a program for individual and organizational development. Journal of Workplace Learning, 11(8), pp.291-297

Brockbank, A. and McGill, I. 2012. Facilitating reflective learning: coaching, mentoring and supervision, $2^{\text {nd }}$ ed. London: Kogan Page Publishers

Brannback, M. and Carsrud, A. L. (2016), Understanding entrepreneurial cognitions through the lenses of context, In: F. Welter and W. B. Gartner (eds.), A Research Agenda for Entrepreneurship and Context, Cheltenham, Edward Elgar, pp. 16-27

Blundel, R., Lockett, N. and Wang, C. (2017), Exploring entrepreneurship, $2^{\text {nd }}$ ed, Sage, London, Publication Ltd

Cairns-Lee, H. (2015), Images of leadership development from the inside out. Advances in Developing Human Resources, 17(3), pp.321-336

Coffield, F., Moseley, D., Hall, E. and Ecclestone, K., (2004), Learning styles and pedagogy in post-16 learning: A systematic and critical review. Trowbridge, learning skills research centre. [Internet] available at: http://www.voced.edu.au/content/ngv\%3A13692 [accessed 9th March 2018] 
Cope, J. (2010), Entrepreneurial learning from failure: an interpretative phenomenological analysis. Journal of Business Venturing, 26(6), pp.604 - 623

Cope, J. (2005). Toward a dynamic learning perspective of entrepreneurship, Entrepreneurship Theory and Practice, 29 (4), pp.429-450

Cope, J. (2003), Entrepreneurial learning and critical reflection: discontinuous events as triggers for 'higher-level' learning. Management Learning, 34 (4), pp.441-450

Deakins, D. (1999), Entrepreneurship learning and the growth process in SMEs. The Learning Organisation. 5(3), pp.144-155

Deakins, D. and Freel, M. (1998), Entrepreneurial learning and the growth process in SMEs, The Learning Organisation, 5 (3), pp.144-155

De Haan, E. (2008) I doubt therefore I coach: Critical moments in coaching practice. Consulting Psychology Journal: Practice and Research, 60(1), pp. 91-105

De Haan, E. and Duckworth, A. (2013), Signalling a new trend in executive coaching outcome research. International Coaching Psychology Review, 8(1), pp. 6-19

De Haan, E., Duckworth, A. Birch, D. and Jones, C. (2013), Executive coaching outcome research: the contribution of common factors such as relationship, personality match and selfefficacy. Consulting Psychology Journal: Practice \& Research, 65(1), pp.40-57

De Villiers, R. (2012), Optimising corporate control through executive coaching development: the role of coaching. Corporate Ownership and Control, 10 (1) pp. 559-572

Du Toit, A. (2014) Making sense of coaching. London: Sage Publications Ltd

Ely, K., Boyce, L. A., Nelson, J. K., Zaccaro, S. J., Hernez-Broome, G. and Whyman, W. (2010), Evaluating leadership coaching: a review and integrated framework. The Leadership Quarterly, 21(4), pp.585-599

Garvey, R. (2017), issues of assessment and accreditation of coaches. In: Bachkirova, T., Spence, G. and Drake, D. (eds), Sage handbook of coaching. London: Sage Publications Ltd, pp. 680-895

Garvey, B. (2011), a very short, fairly interesting and reasonably cheap book about coaching and mentoring. London: Sage Publications Ltd 
Garvey, B. (1994), a dose of mentoring. Education + Training, 36(4), pp.18-26

Garvey, R., Stokes, P. and Megginson, D. (2017), coaching and mentoring: theory and practice, $3^{\text {rd }}$ ed. London, Sage Publication Ltd

Garvey, R., Stokes, P. and Megginson, D. (2014), coaching and mentoring: theory and practice. $2^{\text {nd }}$ ed. London: Sage Publication Ltd

Gilbb, A. (1997), Small firms' training and competitiveness: building upon the small business as a learning organisation. International Small Business Journal, 15 (3), pp.13-29

Gibb, A. (2002). In pursuit of a new 'enterprise' and 'entrepreneurship' paradigm for learning, creative destruction, new values, new ways of doing things and new combinations of knowledge, International Journal of Management reviews, 4(3), pp233-269

Giglio, L., Diamante, T. and Urban, J.M. (1998), Coaching a leader: leveraging change at the top. Journal of Management Development and Learning in Organizations, 17(2), pp.93-105

Grant, A. M. (2014), The efficacy of executive coaching in times of organisational change. Journal of Change Management, 14(2), pp.258-280

Grant, A.M., (2012), ROI is a poor measure of coaching success: towards a more holistic approach using a well-being and engagement framework. Coaching: An International Journal of Theory, Research and Practice, 5(2), pp.74-85

Grant, A.M., Curtayne, L. and Burton, G. (2009), Executive coaching enhances goal attainment, resilience and workplace well-being: a randomised controlled study. The Journal of Positive Psychology, 4(5), pp.396-407

Gray, D. E. (2006) Executive coaching: towards a dynamic alliance of psychotherapy and transformative learning processes. Management Learning, 37(4), pp.475-497

Gray, D. E., Garvey, B. and Lane, D. A. (2016), a critical introduction to coaching and mentoring: debates, dialogues and discourses. London: Sage Publications Ltd

Grief, S. (2017), Researching outcomes of coaching. In: Bachkirova, T., Spence, G. and Drake, D. (eds), Sage handbook of coaching. London: Sage Publications Ltd, pp. 570-588 
Hamlin, R. G., Kim, S., Chai, D. S., Kim, J. and Jeong, S. (2016), Perceived managerial and leadership effectiveness within South Korean and British private companies: a derived etic comparative study. Human Resource Development Quarterly, 27(2), pp.237-269

Honey, P. \& Mumford, A. (1982), The manual of learning styles. Maidenhead: Peter Publications

Hudson, F. M. (1999), The handbook of coaching: a comprehensive resource guide for managers, executives, consultants, and human resource professionals. San Francisco: JosseyBass Publishers

Hunt, C.M and Fielden, S.L (2016), Coaching for women entrepreneurs, Cheltenham: Edward Elgar Publishing

Jarvis, P., Holford, J. and Griffin, C. (1998), The theory and practice of learning. London: Kogan Page

Johnston, L., Hamilton, E. and Zhang, J. (2008), Learning through engaging with higher education institutions: a small business perspective. International Small Business Journal, 26(6), pp.651-660

Jones, O., Macpherson, A. and Woollard, D. (2008), Entrepreneurial ventures in higher education: analysing organisational growth. International Small Business Journal. 26 (6), pp. $683-708$

Kilburg, R. R. (1996), Toward a conceptual understanding and definition of executive coaching. Consulting Psychology Journal: Practice and Research, 48(2), pp.134-144

King, P. and Eaton, J. (1999), Coaching for results. Industrial and Commercial Training, 31(4), pp.145-151

Korotov, K. (2017), coaching for leadership development, In: Bachkirova, T., Spence, G. and Drake, D. (eds) Sage Handbook of coaching, London: Sage Publications Ltd, pp.139-158

Knowles, M. (1975), self-directed learning: a guide for learners and teachers. New York: Associated Press

Knowles, M.S. (1984), Andragogy in action: Applying modern principles of adult education. San Francisco: Jossey Bass

Citation for this Chapter: Rajasinghe, D., \& Mansour, H. F. (2019). Coaching as an entrepreneurship learning and development tool. In 23 G. Mulholland \& J. Turner (Eds.), Enterprising education in UK higher education: Challenges for theory and practice (pp. 52-69). London: Routledge. 
Knowles, M. S., Holton, E. F. and Swanson, R.A. (2015), the adult learner: the definitive classic in adult education and human resource development, $8^{\text {th }}$ ed. Oxon: Routledge

Kolb, D.A. (1984), Experiential learning. New Jersey: Prentice Hall

Kolb, D.A. \& Fry, R (1975), Towards an applied theory of experiential learning. In: Cooper, C.L. ed. Theories of group processes. London: John Wiley

Ladegard, G. and Gjerde, S. (2014), Leadership coaching, leader role-efficacy, and trust in subordinates: a mixed methods study assessing leadership coaching as a leadership development tool. The Leadership Quarterly, 25(4), pp. 631-646

Lave J. and Wenger, E. 1991. Situated learning: legitimate peripheral participation, Cambridge: Cambridge University Press

Ling, T. (2012), Evaluating complex and unfolding interventions in real time. Evaluation, 18(1), pp.79-91

MacKie, D. (2016), Strength - based leadership coaching in organisations. London: Kogan Page Limited

Maltbia, T. E., Marsick, V.J. and Ghosh, R. (2014), Executive and organizational coaching a review of insights drawn from literature to inform HRD practice. Advances in Developing Human Resources, 16(2), pp.161-183

Merriam, S. B. (2001), andragogy and self-directed learning: Pillars of adult learning theory, In: Merriam, S.B. Ed. The new update on adult learning theory: new directions for adult and continuing Education. San Francisco: Jossey-Bass, pp. 3-13

Mezirow, J. (2000), Learning as Transformation: critical perspectives on a theory in progress, The Jossey-Bass higher and adult education series, San Francisco: Jossey-Bass

Mezirow, J. (1991), Transformative dimensions of adult learning, San Francisco: Jossey-Bass Northouse, P. G. (2016), leadership: theory and practice. $7^{\text {th }}$ ed. Thousand Oaks: Sage publications Inc.

Narayanasamy, A. and Penney, V. (2014). Coaching to promote professional development in nursing practice, British Journal of Nursing. 23(11), pp. 569-573 
Passmore, J. (2007), An integrative model for executive coaching. Consulting Psychology Journal: Practice and Research, 59 (1), pp.68-78

Passmore, J. and Fillery-Travis, A. (2011), A critical review of executive coaching research: a decade of progress and what's to come. Coaching: An International Journal of Theory, Research and Practice, 4(2), pp. 70-88

Penaluna, A. \& Penaluna, K. (2008), Entrepreneurial Capacity? Entrepreneurial Intent? Assessing creativity: drawing from the experience of the UK's creative industries. Paper presented at IntEnt 2008, Miami University, Ohio

Piaget, J. (1929), the child's conception of the world. London: Routledge and Kegan Paul

Pittaway, L. (2000), The Social Construction of Entrepreneurial Behaviour, PhD Thesis, The University of Newcastle-upon-Tyne, UK

Pittaway, L, Gazzard, J. Shore A. and Williamso, T. (2015), Student clubs: experiences in entrepreneurial learning. Entrepreneurship and Regional Development, 27 (3-4), pp.127-153

Pittaway, L. and Thorpe, R. (2012), a framework for entrepreneurial learning: a tribute to Jason Cope. Entrepreneurship and Regional Development, 24 (9/10), pp.837-859

Pavlov, I.P. (1927), Conditioned reflexes. London: Routledge and Kegan Paul

QAA (Quality Assurance Agency) (2018), Enterprise and Entrepreneurship Education: Guidance for UK Higher Education Providers (January), [online], Available at: http://www.qaa.ac.uk/en/Publications/Documents/Enterprise-and-entrepreneurshipeducation-2018.pdf [Accessed: 20th February 2018]

Rae, D. (2002), Entrepreneurial emergence: A narrative study of entrepreneurial learning in independently owned media business. International Journal of Entrepreneurship and Innovation. 3 (1), pp. 53-59

Rae, D. and Carswell, M. (2000), Using a life story approach to researching entrepreneurial learning: the development of a conceptual model and its implications in the design of learning experiences. Education and Training. 42 (4/5), pp. 220-227

Reynolds, J. and Mason, R. (2002), How do people learn? London: CIPD Publishing

Citation for this Chapter: Rajasinghe, D., \& Mansour, H. F. (2019). Coaching as an entrepreneurship learning and development tool. In 25 G. Mulholland \& J. Turner (Eds.), Enterprising education in UK higher education: Challenges for theory and practice (pp. 52-69). London: Routledge. 
Saunders, M. (2006), The 'presence 'of evaluation theory and practice in educational and social development: toward an inclusive approach. London Review of Education, 4(2), pp.197-215

Segers, J., Vloeberghs, D., Henderickx, E. and Inceoglu, I. (2011), Structuring and understanding the coaching industry: the coaching cube. Academy of Management Learning \& Education, 10(2), pp. 204-221

Schwandt, T. A. (1997) Evaluation as practical hermeneutics. Evaluation. 3(1), pp. 69-83

Skinner, B.F. (1976), about behaviourism. New York: Random House

Starr, J. (2003), the coaching manual: the definitive guide to the process, principles and skills of personal coaching, London: Prentice Hall Business

Stern, L. R. (2004), Executive coaching: a working definition. Consulting Psychology Journal: Practice and Research, 56(3), pp.154-162

Theeboom, T., Beersma, B. and Van Vianen, A.E. (2014), Does coaching work? A metaanalysis on the effects of coaching on individual level outcomes in an organizational context. The Journal of Positive Psychology, 9(1), pp.1-18

Thompson, J., \& Downing, R., (2007), The entrepreneur enabler: identifying and supporting those with potential. Journal of Small Business and Enterprise Development, 14(3), 528-544.

Tobias, L. L. (1996), Coaching executives. Consulting Psychology Journal: Practice and Research, 48(2), pp. 87-95

Tseng, C. (2013), Connecting self-directed learning with entrepreneurial learning to entrepreneurial performance. International Journal of Entrepreneurial Behaviour Research, 19(4), pp. 425 - 446

Underhill, B. O., McAnally, K. and Koriath, J.J. (2007), Executive coaching for results: the definitive guide to developing organizational leaders, San Francisco: Berrett-Koehler Publishers Inc.

Vygotsky, L.S. (1978), mind in society: the development of higher psychological process. Eds. Cole, M., John-Steiner, V., Scribner, S. and Souberman, E. Cambridge, MA: Harvard University Press

Citation for this Chapter: Rajasinghe, D., \& Mansour, H. F. (2019). Coaching as an entrepreneurship learning and development tool. In 26 G. Mulholland \& J. Turner (Eds.), Enterprising education in UK higher education: Challenges for theory and practice (pp. 52-69). London: Routledge. 
Wang, Q. (2012) Coaching for Learning: exploring coaching psychology in enquiry-based learning and development of learning power in secondary education, Procedia - Social and Behavioural Sciences, 69, pp.177-186

Watts, G., Cope, J. and Hulme, M. (1998), Pain and gain: growth strategies and adaptive learning among small food producers. International Journal of Entrepreneurship Behaviour and Research, 4(2), pp.101 - 111

Western, S. (2012) Coaching and mentoring: a critical text, London: Sage Publications Ltd Whitmore, J. (2012), Coaching for performance: growing human potential and purpose, the principles and practice of coaching and leadership, London: Nicholas Brealey Publishing

Wilson, C. (2007), Best practice in performance coaching: a handbook for leaders, coaches, HR professionals and organizations. London: Kogan.

Wilson, K. (2008). Entrepreneurship Education in Europe. Entrepreneurship and Higher $\begin{array}{lllll}\text { Education. } & \text { Retrieved } & \text { March } & \text { 29, from }\end{array}$ http://www.oecd.org/dataoecd/10/13/42961567.pdf

Witherspoon, R. and White, R.P. (1996), Executive coaching: A continuum of roles. Consulting Psychology Journal: Practice and Research, 48(2), pp.124-133

Wood, D., Bruner, J.S. and Ross, G (1976), the role of tutoring in problem-solving, Journal of child psychology and psychiatry, 17(2), pp.89-100

Zeus, P., and Skiffington, S. (2000), The complete guide to coaching at work, North Ryde: McGraw Hill Australia. 